University of Nebraska - Lincoln

DigitalCommons@University of Nebraska - Lincoln

Publications from USDA-ARS / UNL Faculty

U.S. Department of Agriculture: Agricultural

Research Service, Lincoln, Nebraska

2004

\title{
Texture Profile Analysis and Composition of a Minced Catfish Product
}

J. Lee Wiles

USDA, Agricultural Research Service

Bartholomew W. Green

USDA, Agricultural Research Service, bart.green@usda.gov

R. Bryant

USDA, Agricultural Research Service

Follow this and additional works at: https://digitalcommons.unl.edu/usdaarsfacpub

Part of the Agriculture Commons, and the Aquaculture and Fisheries Commons

Wiles, J. Lee; Green, Bartholomew W.; and Bryant, R., "Texture Profile Analysis and Composition of a Minced Catfish Product" (2004). Publications from USDA-ARS / UNL Faculty. 2471.

https://digitalcommons.unl.edu/usdaarsfacpub/2471

This Article is brought to you for free and open access by the U.S. Department of Agriculture: Agricultural Research Service, Lincoln, Nebraska at DigitalCommons@University of Nebraska - Lincoln. It has been accepted for inclusion in Publications from USDA-ARS / UNL Faculty by an authorized administrator of DigitalCommons@University of Nebraska - Lincoln. 


\title{
TEXTURE PROFILE ANALYSIS AND COMPOSITION OF A MINCED CATFISH PRODUCT ${ }^{1}$
}

\author{
J.L. WILES and B.W. GREEN ${ }^{2}$ \\ United States Department of Agriculture \\ Agricultural Research Service \\ Aquaculture Systems Research Unit \\ 1200 North University $\mathrm{Dr}$. \\ Pine Bluff, AR 71601
}

AND

R. BRYANT

United States Department of Agriculture

Agricultural Research Service

Dale Bumpers National Rice Research Center

Stuttgart, AR 72160

(Manuscript received August 25, 2003; in final form May 6, 2004)

\begin{abstract}
Texture Profile Analysis of minced catfish products indicated that minced proteins from the belly flap meat have excellent functional properties to form gels or restructured products. Belly flap meat is considered a low-value trimming, with about $16.9 \%$ protein and $11.2 \%$ total lipid. Washing of minced catfish trimmings increased the moisture content from $71.5 \%$ to $77.9 \%$ while reducing mechanical hardness $(19.1 \mathrm{~N}$ to $11.9 \mathrm{~N})$, chewiness index $(14.2 \mathrm{~N}$ to $8.83 \mathrm{~N})$ and shear energy $(0.82 \mathrm{~J}$ to $0.51 \mathrm{~J})$. No significant changes were found in cohesiveness, resilience, and springiness of the minced fish after washing or the addition of $3.3 \%(\mathrm{v} / \mathrm{w})$ of $4 \%$ starch solution. Washing of minced fish reduced the total lipid content from $9.82 \%$ to $4.39 \%$. Overall, washed minced channel catfish belly flap meat had functional characteristics that enabled its proteins to be formed and restructured. Products made from minced catfish had acceptable textural characteristics.
\end{abstract}

${ }^{1}$ Mention of trade names or commercial products in this publication is solely for the purpose of providing specific information and does not imply recommendation or endorsement by the U.S. Department of Agriculture.

${ }^{2}$ Corresponding author. EMAIL: bgreen@spa.ars.usda.gov 


\section{INTRODUCTION}

Integration of food technology into the processing of farm-raised channel catfish (Ictalurus punctatus) to develop and enhance new products from mis-cut fillets, belly flap meat, and carcass trimmings makes the process more economically efficient and may reduce processing waste. Postharvest handling and processing methods to reduce the fat content in the belly flap meat of channel catfish will enhance the quality, functionality, and sensory characteristics of its value-added products. Researchers have determined that fish meat characteristics such as fat, water, protein and ash contents vary within sections of the fillet of fish (Morkore et al. 2002). The belly flap meat of channel catfish is considered to be high in fat content that is responsible for limited shelf-life and undesirable sensory qualities. Sathivel et al. (2000) reported that channel catfish belly flap meat contained nearly $15 \%$ fat compared to $9 \%$ fat in fillet meat. In the belly flap meat, the dominant unsaturated fatty acid is oleic acid $(175.7 \mathrm{mg} / \mathrm{g}$ on a dry basis). These authors also found $18.6 \mathrm{mg} / \mathrm{g}$ total $\mathrm{n}-3$ (omega-3) fatty acids in belly flap meat and $15.3 \mathrm{mg} / \mathrm{g}$ in fillets (Sathivel et al. 2000). Omega-3 fatty acids, together with the omega-6 fatty acids, are important components of a healthful diet.

Interest in comminuted or minced fish products is stimulated by the successful use of mechanical deboning equipment and techniques for reshaping minced fish flesh into commercially acceptable products. Factors affecting textural characteristics of cooked comminuted fish muscle include time of comminution, presence of $\mathrm{NaCl}$ and polyphosphates, effect of mechanical deboning, setting temperature, and type of heating medium used (Lee 1976). The presence of polyphosphates increased protein solubilization and improved water binding.

Suvanich et al. (2000) found that quality changes of comminuted catfish muscle resulted from autolytic chemical reactions, microbial proliferation, and physical property alterations that caused poor functionality and reduced shelf-life of end products. Washing minced fish muscle improved color and sensory properties of final products. Fat content decreased after washing because lipids floated to the surface and are removed. Other substances removed by washing included blood, pigments, odors, enzymes, mucus, and some water-soluble proteins. Reduction of fat content by washing may result in other compositional changes because values were calculated on a total sample weight basis. However, protein content of catfish frame mince was unchanged, likely because of the stoichiometric replacement of fat with water. Decreased ash content in frame mince following washing likely resulted from the removal of watersoluble mineral constituents. While washing of catfish protein decreased the fat content of the meat as compared to unwashed catfish muscle, additional fat reduction was not observed after two or three washings. Lipids in channel 
catfish mince were $50 \%$ monounsaturated, $30 \%$ saturated, and $20 \%$ polyunsaturated fatty acids. Constituent fatty acids were palmitic, stearic, palmitoleic, oleic, and linoleic.

Kim et al. (1996) concluded that catfish surimi derived from frames had functional properties consistent with use for commercial production of shellfish analogs and other fabricated products. Differences in the proximate composition, textural properties, and Hunter color values were found between gels prepared with washed and unwashed surimi. Minced fish is a relatively inexpensive, available source of functional, nutritious protein. The significant quantities of salt soluble protein contained in minced fish can be used in value-added product development. The objective of this study was to develop a formed product from the minced belly flap meat of farm-raised channel catfish, and evaluate its textural profile attributes and composition.

\section{MATERIALS AND METHODS}

\section{Fish Product Preparation}

A $22.7 \mathrm{~kg}$ box of fresh channel catfish belly flap meat was purchased from an Arkansas fish processor. The belly flap meat was injected with a $6 \%$ solution of sodium tripolyphosphate, sodium chloride, hexametaphosphate, and citric acid (Southern Chemical Service, West Point, MS) by needle injector to $10 \%$ rate by weight during processing. This is a processing standard of the processor and is common throughout the U.S. channel catfish processing industry. Upon arrival at the laboratory, an initial sample of belly flap meat was taken for proximate and $\mathrm{pH}$ analysis before the belly flap meat was frozen at $-20 \mathrm{C}$ in a freezer (True Manufacturing Co., St. Louis, MO).

Belly flap meat was thawed and ground (Biro Mfg. Co., Model 722, 9.5 $\mathrm{cm}$ plate, Marblehead, Ohio) to prepare a minced fish product. Minced fish was washed once with a water temperature $<10 \mathrm{C}$ using $1 \mathrm{~L}$ of distilled water per $400 \mathrm{~g}$ of mince. The experimental design comprised two controls and three binders. Washed and unwashed mince without binder served as the controls. Rice flour (Riceland Foods, Stuttgart, AR), tapioca flour (Multi-Kem Corp., Ridgefield, NJ), or locust bean gum (Multi-Kem Corp., Ridgefield, NJ) were each prepared as a $4 \%$ solution. The number of replicates for each analysis is noted below. The entire experiment was repeated two times.

Sodium chloride $(2.4 \% \mathrm{w} / \mathrm{w})$ (Cargill Alberger, St. Clair, MI) and binder solution $(3.3 \% \mathrm{v} / \mathrm{w})$ were combined with fish mince. Only sodium chloride was added to controls. The mixtures were homogenized for $4 \mathrm{~min}$ at 10,000 RPM (VirtiShear Cyclone IQ2, Gardiner, NY). Following homogenization, the fish mixture was encased (Sealed Air, CN405 casings, Springdale, AR), placed into 
a 90C water bath (VWR, Sheldon Mfg., Comelius, OR) for $30 \mathrm{~min}$, and then refrigerated at $4 \mathrm{C}$ overnight.

\section{Proximate Analyses}

All samples for proximate analysis were dried prior to analysis at $105 \mathrm{C}$ in a gravity convection oven (Fisher Isotemp, Fisher Scientific, Pittsburgh, PA) for $1 \mathrm{~h}$. Samples were cooled in a desiccator prior to analysis. There were three replicates for each experimental treatment.

Lipid content was measured according to the AOAC Official Method 991.36 "Fat (crude) in Meat and Meat Products" (Solvent Extraction Method) (AOAC 1990) using a 2050 Soxtec Avanti (Foss Tecator, Hoganas, Sweden).

Protein content was determined according to AOAC Official Method 992.15 "Crude Protein in Meat and Meat Products" (Combustion Method) (AOAC 1990) using a LECO FP-2000 Protein Analyzer (LECO Corp., St. Joseph, MI). Protein content was calculated as nitrogen content multiplied by 6.25 . Ethylene diaminetetra-acetic acid (EDTA) was used as a calibration standard.

Ash content was measured as outlined by Woyewoda et al. (1986). Predried fish samples were heated at $550 \mathrm{C}$ overnight using a muffle furnace (Thermolyne 4800, Barnstead International, Dubuque, Iowa). Ash weights were recorded to the nearest $0.0001 \mathrm{~g}$ using an Acculab balance (Model LA-2000, Newtown, PA). Moisture content was performed as outlined by Woyewoda et al. (1986) using $5 \mathrm{~g}$ of sample, oven (Lab-Line, Melrose Park, IL) dried at $105 \mathrm{C}$ for $24 \mathrm{~h}$. Percentage of moisture content was calculated using the initial sample weight or wet basis.

Measurement of $\mathrm{pH}$ was performed on a Corning $\mathrm{pH}$ meter (model 440 , Corning, NY) using $20 \mathrm{~g}$ of fish product with $40 \mathrm{~mL}$ of distilled water. Fish solution was homogenized at 10,000 RPM for $1 \mathrm{~min}$ using a VirtiShear Cyclone IQ2 homogenizer (VirTis Co., Gardiner, NY).

\section{Color Measurements}

CIE (Commission Internationale de l'Eclairage) $L^{*}, a^{*}$, and $b^{*}$ were measured using a X-Rite SP62 Spectrophotometer (X-Rite, Grandville, MI) in the specular include mode with an aperture of $4 \mathrm{~mm}$. Quadruplicate replications were performed for each experimental treatment. Park (2000) determined that defining whiteness using $L^{*}$ (lightness) and $b^{*}$ (yellowness-blueness) is the best indicator of the color quality of whiteness for surimi type fish products. Thus, in the present work whiteness was calculated using the equation $\mathrm{L}^{*}-3 b^{*}$ (Park $2000)$. Total color difference $(\Delta E)$ of belly flap and minced catfish products as compared to a catfish fillet was calculated using the following equation (Woyewoda et al. 1986). 


$$
\Delta E=\left[\left(\Delta L^{*}\right)^{2}+\left(\Delta a^{*}\right)^{2}+\left(\Delta b^{*}\right)^{2}\right]^{1 / 2}
$$

\section{Texture Profile Analysis}

Samples (30 $\mathrm{mm}$ in diameter, $15 \mathrm{~mm}$ in length) of each fish mince product were subjected to a Texture Profile Analysis (TPA) to calculate hardness, springiness, cohesiveness, resilience, and chewiness index. The TPA test involved compressing the sample to $35 \%$ of its initial height, withdrawing to the original height, followed by a second compression-withdrawal cycle after allowing the sample to rest for $0.5 \mathrm{~s}$. A TA.XT2i Texture Analyzer (Texture Technologies Corp., Scarsdale, NY) equipped with a $7.6 \mathrm{~cm}$ diameter plate was used for the TPA. Test speed was $5.0 \mathrm{~mm} / \mathrm{s}$ according to Texture Technologies Corporation Study 30WD (2003). There were six replicates for each experimental treatment.

The hardness value is the peak force of the first compression of the product (Bourne 2002). Springiness is how well a product physically springs back after it has been deformed during the first compression (Bourne 2002). Resilience is the percentage of the area under the curve from point 2 to 3 divided by the area under the curve from point 1 to 2 in the first compression. Resilience is a measurement of how a sample recovers from deformation in relation to speed and forces derived (Szczesniak 1963).

Cohesiveness is how well the product withstands a second deformation relative to how it behaved under the first deformation (Bourne 2002). Cohesiveness is the measurement of the area under the second curve divided by the area under the first curve. Chewiness is the energy required to chew a solid food product to a state where it is ready for swallowing (Szczesniak 1963). Chewiness Index is the product of hardness $\times$ cohesiveness $\times$ springiness.

Sample firmness was measured using the TA.XT2i Texture Analyzer equipped with a Kramer shear test cell (5 blades). Quadruplicate replications were performed for each experimental treatment. A test speed of $3.0 \mathrm{~mm} / \mathrm{s}$ according to Texture Technologies Corporation Study 28W (2003) over a sample test height of $25 \mathrm{~mm}$ allowed the measurement of the total work (J) to cut through the sample and the highest force of resistance (peak force, $N$ ).

\section{Statistical Analysis}

This study was randomized and duplicated with 2 separate experiments. Data from the two experiments were pooled and analyzed by one-way analysis of variance with differences among treatment means determined by Duncan's Multiple Range Test (SAS 1990). A level of 0.05 was used to determine significance. 


\section{RESULTS AND DISCUSSION}

Results of proximate analyses are shown in Table 1 . Washing caused a significant decrease in tissue protein and lipid content compared to belly flap meat and nonwashed mince. The washing process effectively removed fats and water-soluble substances, such as sarcoplasmic proteins. Elevated ash contents in minced products are due to the tissues containing sodium polyphosphates and salt in the formed product. Minced fish tissues contained sodium polyphosphates and sodium chloride $(\mathrm{NaCl})$ that are used to solubilize the myofibrillar proteins, which promote protein gel formation. Yetim and Ockerman (1994) observed an ash content as high as $2.8 \%$ in their catfish, which resulted from additives to the fish product.

TABLE 1.

PROXIMATE ANALYSES OF CHANNEL CATFISH BELLY FLAP MEAT, WASHED AND NONWASHED MINCE, AND FORMED COMMINUTED CATFISH PRODUCTS (WET BASIS)

\begin{tabular}{lcccc}
\hline Sample & Protein (\%) & l.ipid (\%) & Ash (\%) & Moisture (\%) \\
\hline Bellỵ flap meat & $16.9^{\mathrm{a}}$ & $11.2^{\mathrm{a}}$ & $0.88^{\mathrm{b}}$ & $72.6^{\mathrm{b}, \mathrm{c}}$ \\
Non-washed mince & $16.4^{\mathrm{a}}$ & $9.82^{\mathrm{a}}$ & $2.28^{\mathrm{a}}$ & $71.5^{\mathrm{c}}$ \\
Washed mince & $12.6^{\mathrm{b}}$ & $4.39^{\mathrm{b}}$ & $2.48^{\mathrm{a}}$ & $77.9^{\mathrm{b} . \mathrm{a}}$ \\
Mince/Rice Flour & $12.1^{\mathrm{b}}$ & $4.27^{\mathrm{b}}$ & $2.23^{\mathrm{a}}$ & $79.8^{\mathrm{a}}$ \\
Mince/Tapioca Flour & $12.5^{\mathrm{b}}$ & $5.79^{\mathrm{b}}$ & $2.09^{\mathrm{a}}$ & $77.5^{\mathrm{a}}$ \\
Mince/Locust Bean Gum & $11.5^{\mathrm{b}}$ & $5.39^{\mathrm{b}}$ & $2.29^{\mathrm{a}}$ & $79.1^{\mathrm{a}}$ \\
\hline
\end{tabular}

Means of 3 observations per treatment per experiment.

-dMeans within columns followed by different superscripts are significantly different $(P<0.05)$. 'Belly flap meat without sodium tripolyphosphate and salt added, taken from channel catfish harvested from research ponds at the University of Arkansas at Pine Bluff.

The moisture content in the washed and nonwashed minced catfish product ranged from $70-80 \%$ (Table 1 ). Washing of mince and the addition of binding agents significantly increased the percentage of moisture in the product as compared to nonwashed minced catfish, which did not differ significantly from belly flap meat. The quantity of water affects the color, texture and flavor characteristics of the finished product (Park 2000). The initial pH of the belly 
flap meat was 7.0 but increased to $\mathrm{pH} 7.2$ after washing removed water-soluble acids. All minced fish products had $\mathrm{pH}$ readings in the range of 6.9 to 6.7 . Similar $\mathrm{pH}$ results have been observed for minced fish products by other researchers (Suvanich et al. 2000; Yetim and Ockerman 1994).

Fillet meat had the highest luminance ( $\left.\mathrm{L}^{*}\right)$ value (Table 2$)$. The $\mathrm{L}^{*}$ of the unprocessed belly flap meat was significantly lower than the fillet, washed and nonwashed minced fish, and the mince/rice flour and mince/locust bean gum products (Table 2 ). Whiteness, often a determinant of color quality of minced fish and calculated as $\mathrm{L}^{*}$ - $3 \mathrm{~b}^{*}$ (Park 2000), did not differ significantly among many of the products (Table 2 ). Inclusion of binders did not significantly affect product whiteness. Nonwashed mince was significantly less white than washed mince and the mince/rice flour and mince/locust bean gum products. The color difference was greatest between fillet and belly flap meat, followed by the mince/tapioca flour product followed by the remaining forms or products (Table 2). The adhered peritoneal membrane on the belly flap gave it a darker

TABLE 2.

COLOR CIE VALUES" OF WHOLE CHANNEL CATFISH FILLETS, BELLY FLAP MEAT, AND VARIOUS MINCED PRODUCTS

\begin{tabular}{lccccc}
\hline Sample & $\mathrm{L}^{*}$ & $\mathrm{a}^{*}$ & $\mathrm{~b}^{*}$ & Whiteness $^{1}$ & Color \\
& & & & & Difference $^{2}$ \\
\hline Fillet & $72.1^{\mathrm{a}}$ & $-1.30^{\mathrm{a}, \mathrm{b}}$ & $11.0^{\mathrm{b}}$ & $39.2^{\mathrm{a}, \mathrm{b}, \mathrm{c}}$ & $\mathrm{n} / \mathrm{a}$ \\
Belly Flap & $58.5^{\mathrm{d}}$ & $-1.48^{\mathrm{c}, \mathrm{b}}$ & $8.11^{\mathrm{b}}$ & $34.2^{\mathrm{b}, \mathrm{c}}$ & $14.4^{\mathrm{a}}$ \\
Non-washed Mince & $66.4^{\mathrm{b}}$ & $-1.14^{\mathrm{a}}$ & $11.0^{\mathrm{a}}$ & $33.5^{\mathrm{c}}$ & $7.61^{\mathrm{c}}$ \\
Washed Mince & $65.9^{\mathrm{b}, \mathrm{c}}$ & $-1.58^{\mathrm{c}}$ & $7.10^{\mathrm{b}}$ & $44.6^{\mathrm{b}, \mathrm{a}}$ & $9.74^{\mathrm{b}, \mathrm{c}}$ \\
Mince/Rice Flour & $64.9^{\mathrm{b}, \mathrm{c}}$ & $-1.44^{\mathrm{b}, \mathrm{c}}$ & $6.13^{\mathrm{b}}$ & $46.5^{\mathrm{a}}$ & $10.3^{\mathrm{b}, \mathrm{c}}$ \\
Mince/Tapioca Flour & $61.8^{\mathrm{c}, \mathrm{d}}$ & $-1.69^{\mathrm{c}}$ & $5.95^{\mathrm{b}}$ & $43.9^{\mathrm{ab}, \mathrm{c}}$ & $13.1^{\mathrm{a}, \mathrm{b}}$ \\
Mince/Locust Bean Gum & $66.6^{\mathrm{b}}$ & $-1.63^{\mathrm{c}}$ & $7.29^{\mathrm{b}}$ & $44.7^{\mathrm{a}, \mathrm{b}}$ & $8.28^{\mathrm{c}}$ \\
\hline
\end{tabular}

Means of 4 observations per treatment per experiment.

${ }^{2-d}$ Means within columns followed by different superscripts are significantly different $(P<0.05)$.

${ }^{1}$ Whiteness $=L^{*}-3 b^{*}$ as defined by Park (2000).

${ }^{2}$ Color Difference (compared to fillet) $=\left[\left(\Delta L^{*}\right)^{2}+\left(\Delta a^{*}\right)^{2}+\left(\Delta b^{*}\right)^{2}\right\}^{1 / 2}$ 
color. Washing of proteins resulted in whiter tissues or products due to the removal of blood, pigments, and water-soluble proteins; however, the presence of specs of comminuted peritoneal membrane resulted in grayish or dark areas on certain points of the product.

A plot of the products' whiteness and moisture contents revealed a positive linear relationship (Fig. 1). A similar positive whiteness-moisture content relationship was found for surimi (Reppond and Babbitt 1997). A greater percentage of moisture was found in the washed mince and in the mince/binder (rice flour, tapioca flour, locust bean gum) products (Table 1). The presence of sodium tripolyphosphate in belly flap meat and the inclusion of a starch binder increased water retention in the product matrix, particularly after washing. Park (2000) states that the addition of water to surimi changed the color hues of the gels such that the $L^{*}$ values increased and $b^{*}$ values decreased as the amount of water increased.

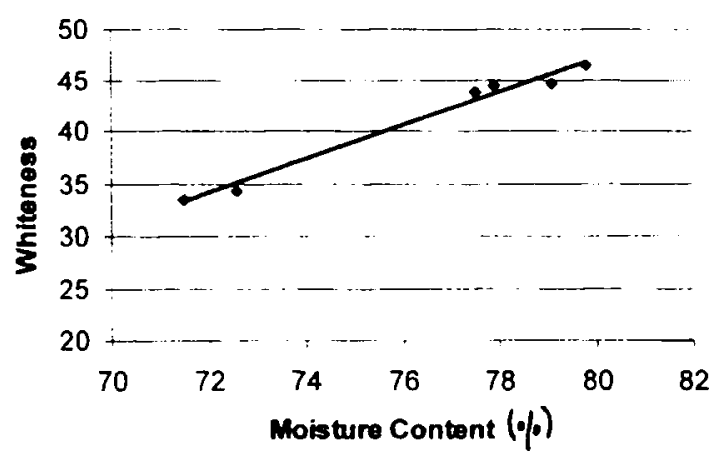

FIG. 1. RELATIONSHIP BETWEEN THE AVERAGE WHITENESS (L* - 3b* AS DEFINED BY PARK 2000) AND MOISTURE CONTENT OF MINCED CHANNEL CATFISH PRODUCTS

Texture Profile Analysis results (Table 3) demonstrated that the belly flap meat and nonwashed minced fish had significantly greater values for hardness and chewiness index. The addition of binding agents such as tapioca flour, rice flour, and locust bean gum lowered the values for hardness and chewiness in the product. No significant differences were observed for the cohesiveness, resilience, and springiness among the products. Figure 2 illustrates a typical TPA of minced catfish. Lee et al. (1996) stated that the textural strength of cooked muscle diminished with increased moisture content. Our results, confirmed that the washed mince products had higher moisture content and lower strength compared to belly flap meat and nonwashed mince. 
TABLE 3.

TEXTURE PROFILE ANALYSIS OF MECHANICAL CHARACTERISTICS OF CHANNEL CATFISH BELLY FLAP MEAT, WASHED AND NONWASHED MINCE, AND FORMED COMMINUTED CATFISH PRODUCTS. (SPRINGINESS IS NOT REPORTED BECAUSE ALL SAMPLES HAD MEAN VALUES OF 99 TO 100\%.)

\begin{tabular}{|c|c|c|c|c|}
\hline Sample & $\begin{array}{c}\text { Hardness } \\
\text { (N) }\end{array}$ & $\begin{array}{c}\text { Cohesiveness } \\
(\%)\end{array}$ & $\begin{array}{c}\text { Resilience } \\
(\%)\end{array}$ & $\begin{array}{l}\text { Chewiness } \\
\text { Index (N) }\end{array}$ \\
\hline Belly Flap Meat ${ }^{\top}$ & $18.8^{\mathrm{a}}$ & $66.0^{\mathrm{a}}$ & $45.2^{\mathrm{a}}$ & $12.4^{\mathrm{a}}$ \\
\hline Non-washed Mince & $19.1^{\mathrm{a}}$ & $73.6^{\mathrm{a}}$ & $47.0^{\mathrm{a}}$ & $14.1^{\mathrm{a}}$ \\
\hline Washed Mince & $11.9^{b}$ & $74.1^{a}$ & $48.2^{\mathrm{a}}$ & $8.83^{b}$ \\
\hline Mince/Rice Flour & $7.32^{c}$ & $70.4^{\mathrm{a}}$ & $45.6^{\mathrm{a}}$ & $5.26^{c}$ \\
\hline Mince/Tapioca Flour & $7.04^{c}$ & $72.8^{\mathrm{a}}$ & $47.4^{\mathrm{a}}$ & $5.11^{c}$ \\
\hline Mince/Locust Bean Gum & $6.56^{c}$ & $72.7^{\mathrm{a}}$ & $47.1^{\mathrm{a}}$ & $4.83^{c}$ \\
\hline
\end{tabular}

Means of 6 observations per treatment per experiment.

${ }^{2-}$ Means within columns followed by different superscripts are significantly different $(P<0.05)$.

'Belly flap meat was heated at $90 \mathrm{C}$ for 30 min before testing.

Washing of minced fish increased the moisture content and the loss of water-soluble proteins (sarcoplasmic) that may aid in the setting of proteins, therefore reducing the textural properties. Setting is the transition of protein molecules from orderly helical conformation to a random coil configuration in which protein molecules intertwine, thus enabling more disulfide and other bonds to form upon heating (Lanier 1980). Myosin is the primary salt-soluble protein active in gel formation, while sarcoplasmic protein is a poor binder of meat pieces (Lanier 1980). At salt concentrations of 1.2 and $1.4 \mathrm{M}$, actomyosin and myosin demonstrated similar binding characteristics (Macfarlane 1977). Actomyosin is less soluble in solutions of low salt concentrations than myosin. Sarcoplasmic protein enhanced the binding strength of myosin at low ionic strengths (Macfarlane 1977). It decreased the binding strength at higher salt concentrations possibly because of a salt induced denaturation or precipitation of sarcoplasmic proteins (Macfarlane 1977). These studies reinforce the findings in this study concerning the superior textural properties of unwashed fish. 


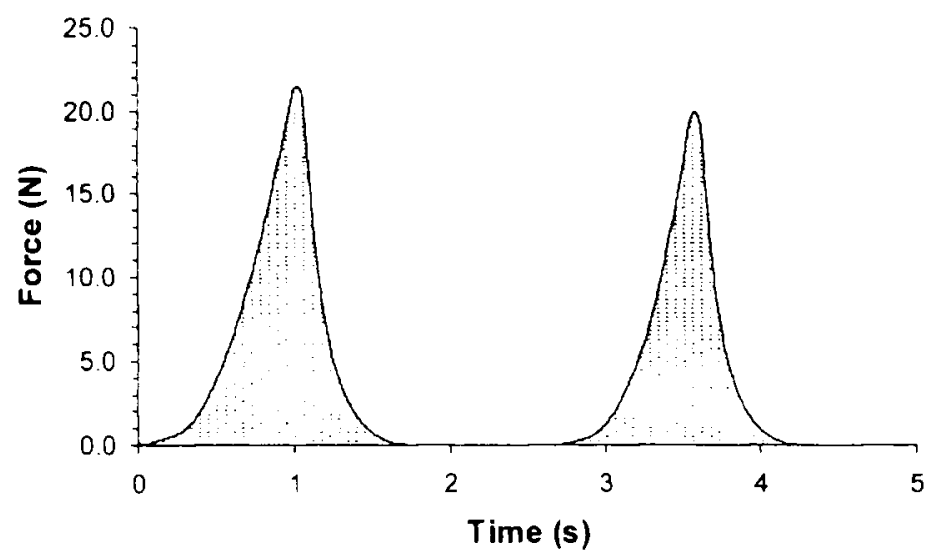

FIG. 2. TYPICAL TEXTURE PROFILE ANALYSIS OF MINCED CATFISH USING TWO COMPRESSIONS AT 35\% OF SPECIMEN HEIGHT AND 0.5-s PAUSE BETWEEN COMPRESSIONS

Mckenna et al. (2003) reported a Kramer Shear Force of 129 to $168 \mathrm{~N}$ for cooked-reheated catfish fillets subjected to various processing treatments. The minced catfish products in the present study had a peak force ranging from 43.8 to $20.3 \mathrm{~N}$ (Table 4). The cooked belly flap meat peak force of resistance exceeded $49 \mathrm{~N}$, the maximum range of the load cell, primarily because of the adhered peritoneal membrane. Product moisture content and the loss of sarcoplasmic proteins that could possibly enhance binding characteristics of the product were accountable for the significant reduction in Kramer Shear force observed in washed minced products. Another factor is that the proteolytic enzymes found in most fish can disintegrate the protein network reducing its textural and firmness properties. Proteases can be controlled by rapid and thorough evisceration of fish following harvest, avoidance of parasitized fish, and minimization of time held in the temperature zone of enzyme activation (Lanier 2000).

Overall, washed minced channel catfish belly flap meat has functional characteristics that enable its proteins to be formed and restructured. Products made from minced catfish have acceptable textural characteristics. Improved water retention capabilities can be achieved through the addition of polyphosphates and starch binders. Finding ways to remove the adhered peritoneal membrane from the belly flap meat can improve the product whiteness, which should improve the visual appearance of a minced product. Washing the minced fish produced a product that had improved functional and color characteristics because of the removal of lipids and water-soluble compounds such as pigments and proteases. 
TABLE 4.

KRAMER SHEAR TEST RESULTS* FOR CHANNEL CATFISH WASHED AND NONWASHED MINCE, AND FORMED COMMINUTED CATFISH PRODUCTS. (NOTE THAT COOKED BELLY FLAP MEAT PEAK FORCE OF RESISTANCE EXCEEDED 49.0 N, THE MAXIMUM RANGE OF THE LOAD CELL.)

\begin{tabular}{|c|c|c|c|}
\hline Sample & $\begin{array}{l}\text { Peak Force of Resistance } \\
\text { (N) }\end{array}$ & Shear Energy (J) & $\begin{array}{l}\text { Shear Stress } \\
\qquad\left(\mathrm{kN} / \mathrm{m}^{2}\right)\end{array}$ \\
\hline Nonwashed Mince & $43.8^{\circ}$ & $0.82^{2}$ & $36.5^{2}$ \\
\hline Washed Mince & $29.7^{b}$ & $0.51^{b}$ & $22.5^{b}$ \\
\hline Mince/Rice Flour & $24.4^{\circ}$ & $0.37^{\circ}$ & $16.5^{b}$ \\
\hline Mince/Tapioca Flour & $26.8^{\circ}$ & $0.31^{\circ}$ & $13.9^{\circ}$ \\
\hline Mince/Locust Bean Gum & $20.3^{\circ}$ & $0.32^{b}$ & $14.0^{\circ}$ \\
\hline
\end{tabular}

Means of 3 observations per treatment per experiment.

2.b Means within columns followed by different superscripts are significantly different $(P<0.05)$.

\section{REFERENCES}

AOAC. 1990. Official Methods of Analysis, 15th Ed., Association of Official Analytical Chemists, Arlington, VA.

ABIDE, G.P., HEARNSBERGER, J.O. and SILVA, J.L. 1990. Initial fish state and mixing time effects on textural characteristics of a restructured catfish product. J. Food Sci. 55, 1747-1748.

BOURNE, M.C. 1978. Texture profile analysis. Food Technol. 32, 62-66, 72. BOURNE, M.C. 2002. Food Texture and Viscosity: Concept and Measurement. Academic Press, New York.

HOKE, M.E., JAHNCKE, M.L., SILVA, J.L., HEARNSBERGER, J.O., CHAMUL, R.S. and SURIYAPHAN, 0. 2000. Stability of washed frozen mince from channel catfish frames. J. Food Sci. 65, 1083-1086.

JOHNSEN, P.B., CIVILLE, G.V. and VERCELLOTTI, J.R. 1987. A lexicon of pond-raised catfish flavor descriptors. J. Sensory Studies 2, 85-91.

JOHNSEN, P.B. and KELLY, C.A. 1990. A technique for the quantitative sensory evaluation of farm-raised catfish. J. Sensory Studies 4, 189-199. KIM, J.M., LIU, C.H., EUN, J.B., PARK, J.W., OSHIMI, R. HAYASHI, K., OTT, B., ARAMAKI, T., SEKINE, M., HORIKITA, Y., FUJIMOTO, K., AIKAWA, T., WELCH, L. and LONG, R. 1996. Surimi from fillet frames of channel catfish. J. Food Sci. 61, 428-431, 438.

LANIER, T.C. 2000. Surimi gelation chemistry. In Surimi and Surimi Seafood, (J.W. Park, ed.) pp. 237-241, Marcel Dekker, New York. 
LANIER, T.C., LIN, T.S., HAMANN, D.D. and THOMAS, F.B. 1980. Gel formation in comminuted fish systems. In Third National Technical Seminar on Mechanical Recovery and Utilization of Fish Flesh, (R.E. Martin, ed.) pp. 181-207, National Fisheries Institute, Washington, DC.

LEE, C.M. and TOLEDO, R.T. 1976. Factors affecting textural characteristics of cooked comminuted fish muscle. J. Food Sci. 41, 391-397.

LEE, C.M., TREVINO, B. and CHAIYAWAT, M. 1996. A simple method and rapid solvent extraction method for determining total lipids in fish tissue. J. AOAC Intern. 79, 487-492.

LUI, C.H. 1992. Utilization of minced catfish recovered from frames for heatinduced gel products. M.S. Thesis, Mississippi State University, Mississippi State, Miss.

MACFARLANE, J.J., SCHMIDT, G.R. and TURNER, R.H. 1977. Binding of meat pieces: A comparison of myosin, actomyosin, and sarcoplasmic proteins as binding agents. J. Food Sci. 42, 1603-1605.

MCALPIN II, C.R. 1993. An economic analysis of producing surimi from aquaculture products. M.S. Thesis, Mississippi State University, Mississippi State, Miss.

MCKENNA, D.R., NANKE, K.E. and OLSON, D.G. 2003. The effects of irradiation, high hydrostatic pressure, and temperature during pressurization on the characteristics of cooked-reheated salmon and catfish fillets. J. Food Sci. 68, 368-377.

MORKORE, T., HANSEN, A.A., UNANDER, E. and EINEN, O. 2002. Composition, liquid leakage, and mechanical properties of farmed rainbow trout; Variation between fillet sections and the impact of ice and frozen storage. J. Food Sci. 67, 1933-1938.

MURRAY, J.M., EASTON, K. and BEST, D.J. 2001. A study of Chineseorigin and European-origin Australian consumers' texture preferences using a novel extruded product. J. Sensory Studies 16, 485-504.

National Agricultural Statistics Service (NASS). February 21, 2003. Catfish Processing. Agricultural Statistics Board. USDA.

PARK, J.W. 2000. Ingredient Technology and Formulation Development. In Surimi and Surimi Seafood, (J.W. Park, ed.) pp. 381-382, Marcel Dekker, New York.

REPPOND, K.D. and BABBITT, J.K. 1997. Gel properties of surimi from various fish species as affected by moisture content. J. Food Sci. 62, 33-36.

SAS. 1990. Version 8, SAS Institute, Cary, North Carolina.

SATHIVEL, S., PRINYAWIWATKUL, W., GRIMM, C.C., KING, J.M. and LLOYD, S. 2002. FA composition of crude oil recovered from catfish viscera. JAOCS 79, 989-992. 
STONE, A.P. and STANLEY, D.W. 1992. Mechanisms of fish muscle gelation. Food Res. Intern. 25, 381-388.

SUVANICH, M.L., JAHNCKE, M.L. and MARSHALL, D.L. 2000. Changes in selected chemical quality characteristics of channel catfish frame mince during chill and frozen storage. J. Food Sci. 65, 24-29.

SZCZESNIAK, A.S. 1963. Classification of textural characteristics. J. Food Sci. 28, 285-289.

Texture Technologies Corporation. 2003. TA.XT2i application study: $28 \mathrm{~W}$. Texture profile analysis on Diced Tomatoes. Study $28 \mathrm{~W}$.

Texture Technologies Corporation. 2003. TA.XT2i application study: 30WD. Texture profile analysis on bologna. Study $30 \mathrm{WD}$.

WOYEWODA, A.D., SHAW, S.J., KE, P.J. and BURNS, B.G. 1986. Recommended Laboratory Methods for Assessment of Fish Quality. Canadian Technical Report of Fisheries \& Aquatic Sciences, August No. 1448.

YETIM, H. and OCKERMAN, H.W. 1994. The influence of egg white and tumbling on proximate composition and protein fractions of fresh catfish muscle. J. Aquatic Food Product Technol. 3, 25-39. 